\title{
PROBLEMS OF THE EFFICIENCY INCREASING OF TRANSPORTATION BY AIR OF UKRAINIAN SSR (1960-1980)
}

\author{
Anatoliy GORBAN ${ }^{1}$, \\ Kyiv State Maritime Academy, Ukraine
}

\begin{abstract}
The article is devoted to the problems of the efficiency increasing of the air transportation. The difficulties of increasing the efficiency of transportation by air in Ukrainian SSR in 1960-1980 were researched, factors that adversely affected the organization of the transport sector were determined and depicted. The article analyzes what caused such difficulties and it was found out that the causes of these difficulties are connected with the organizational problems of air transport of Ukrainian SSR, which negatively affected the operation of the industry. The central aim of the research is to focus on the main problems of air transport of Ukrainian SSR. So, we should say that the transport operation of those years was distributed too unevenly and was dependent on the population density of the territory of the republic. Purpose of the article is to determine, compile and analyze the factors that negatively affected the organization of air transportation of the Ukrainian republic and reduced the efficiency of its operation. Results of the research shows technical, organization and economical deficiency of air transport of Ukrainian SSR which caused the ineffectiveness of this type of transport and determines the nature of such difficulties. Statement of the problem. During the specified period (1960-1980) the air transport had undergone rapid development. Many new airlines were opened, airports were being built and reconstructed, the terms of exploiting of turbojet aircrafts were increased, the speed of planes was increasing. All these facts ensured safe and reliable air connection of all district centers, connected Ukraine with the other Soviet republics and foreign countries by air corridors. Ukrainian Department of Civil Aviation became the biggest regional Department of the Ministry of Civil Aviation of the USSR. But, at the same time the intensity of the increase of cargo and passenger transportation since 1970s led to accumulation of difficulties of different nature which were connected with both cargo transportation and passenger one. This provides the evidence of insufficient effectiveness of the air industry.
\end{abstract}

Key words: air transport, transport effectiveness, airports, freight and passenger transportation, technical and economic factors.

JEL Classification: A10, A13, L23

\section{Introduction}

After rebuilding the economy (1960-1980) the volume of the passenger and freight transportation by air was constantly growing. The opportunities of aviation in agriculture were more widely used. Air connections were rapidly expanding and quite firmly connected cities of Ukraine with each other and with large industrial centers outside the country. The number of airlines which connected Ukraine with foreign countries also increased. Ukrainian pilots were transporting $12 \%$ of passengers and every 4th citizen of the republic used the air transport. Annually, the airports of Ukraine departed about 13 million of passengers and more than 270 thousand tons of cargo and mail. This was the result of constant introduction of new complex of operating system and new airport areas. But, while planning the development of air and land-based components of air transport, the cost of their operation and maintenance was not properly considered which

Corresponding author:

${ }^{1}$ Department of Social Sciences, Kyiv State Maritime Academy.

E-mail: ekaterinagoroshko@mail.ru affected the overall economic condition and efficiency of air transport.

During Soviet period the development of air transport system was mostly investigated in Ukrainian SSR in the context of the work retrieval system on the whole. And even such comprehensive team works as "History of socialist economy of the Ukrainian SSR" [Tsdavo, 1976] and "Regional problems of the transport system development of the Ukrainian SSR" [Tsdavo, 1976] stressed the achievements of the industry - increase of traffic and carrying capabilities, carrying out technical reconstruction. But there wasn't given an objective analysis of the effectiveness of the transportation by air. Nowadays due to new opportunities to study archive materials concerning activities of civil aviation, which was restricted in Soviet time, researchers got the opportunity to carry out unprejudiced analysis of gains and drawbacks in the affair of air transportation development in $60-80$ s of XX century in the Ukrainian SSR. 


\section{Statistical indicators of air transport}

A major factor that affected the efficient organization of air transportation of the Ukrainian SSR was the fact that the hauling work in Ukraine was distributed too unevenly and depended on the population of a city or industrial region, except for airports serving the resort areas of Crimea, Odessa, Mariupol, Carpathians. Thus, most departures were made from the best equipped airports of the cities which had about one million inhabitants and well-developed network of land transport and from the major resort centers [Tsdavo, 1976]. The evidence of it is given in the table below.

Table 1

The intensity and dynamics of the basic aero hubs of the Ukrainian SSR on the verge of 70-80 years

\begin{tabular}{|l|l|l|l|l|}
\hline Provided MIA Flight & \multicolumn{2}{|l|}{1979} & \multicolumn{2}{l|}{1980} \\
\hline Total & \multicolumn{2}{|l|}{2312691} & \multicolumn{2}{l|}{2520818} \\
\hline Intensity of flights & \multicolumn{2}{|l|}{ Hourly } & Daily \\
\hline Airports & 1979 & 1980 & 1979 & 1980 \\
\hline Boryspil & 1951 & 2148 & 135 & 149 \\
\hline Kharkov & 1790 & 1974 & 145 & 150 \\
\hline Donetsk & 1038 & 1262 & 60 & 78 \\
\hline Simferopol & 803 & 878 & 65 & 75 \\
\hline Kyiv & 648 & 600 & 50 & 48 \\
\hline Lviv & 300 & 350 & 24 & 27 \\
\hline Dnepropetrovsk & 244 & 280 & 30 & 32 \\
\hline
\end{tabular}

$[3,3]$

As the above statistical data show, the leading airports in Ukraine had clearly positive trend of intensification of traffic work. But regional airlines of the Republic were in much worse situation. Their characteristic features often were frequent failure of key indicators of passenger transportation, delays in flights and incomplete downloads. So, for Dnipropetrovsk airports of peripheral joint squadron the characteristic feature was the fact that regularity of flights indicated by the schedule was constantly decreasing and did not exceed $77 \%$. In the 1970 s the number of cases of flight delays and even cancellations sharply increased, which was often «written off» on weather conditions. So in 1975 there were 2062 schedule violations occurred and in 1976 its number increased to 2654 , with a significant number of them, as was defined by inspection $-65 \%$ occurred due to the fault of personnel of of transport organization services [Tsdavo, 1976].

Similar problems occur in the Zaporozhye United Squadron, where the regularity of flight times also were often disrupted. Thus, in 1976 there were 5601cases of delayed flights, including the central schedule 2181 flights. Analysis of the causes of flight delays showed that $90.2 \%$ of them occurred due to poor organization of ground services and only $6.8 \%$ were delayed because of adverse climate conditions [Tsdavo, 1976].

Thus, violation of the regularity of flights on a single centralized schedule become a very serious problem, which was exacerbated each year and affected the overall performance of air transportation.

Thus, in 1975 the regularity performance indicator of the planned flights was $71.9 \%$ and in 1976 - only $67 \%$. That means that during a year the regularity of flights fell almost by $5 \%$, and it is unacceptably high for such hightech organizational and technical system as air transport. Only in 1976 there had been 380 cases of violation of the regularity of flights due to the fault of personnel [Istoria sotsyalystycheskoy economee SSSR, 1980].

As already noted, the chronic failure of transportation plan, low payload, failure to fulfill distance of flights were particularly characteristic feature of $\ll$ regional» airlines.

Thus, in Kirovograd united squadron passenger tariff plan was not fully implemented by $7-8$ thousand of people each year due to failure to depart passengers systematically. Progress data (tonne/kilometers) were not performed, primarily due to low payload of airplanes Jan-40, AN-2. Chronic failure to fulfill medium range of flight options became a phenomenon [Tsdavo, 1976]. Thus, in the Crimea average distance of departures was reduced to 50 $\mathrm{km}$, so that no passenger tariff plans were implemented [Tsdavo, 1976].

But especially unsatisfactory in the «regional airline» was the situation with freight transport plan, which was not generally performed.

Thus, in 1976 the plan volume of freight shipments was not fulfilled by eight airlines, including even such as: Boryspil - 749 tons Odessa - 771 tons, Simferopol 225 tons, Kherson - 229 tons, Kiev - 170 tons Zaporozhye -125 tons, Chernivtsi - 95 t Rivne -31 tons [Tsdavo, 1976].

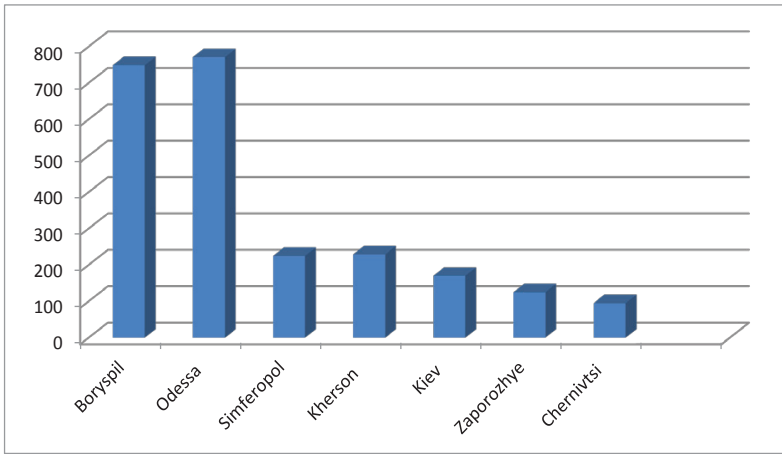

Pic. 1. Volume of cargo delivery of air enterprises (1976)

Thus, despite the relatively rapid overall development of Ukrainian air enterprises, economic efficiency of their work did not meet proper requirements. After all, while 10 years of essential funds and fund supply of airlines increased more than doubled, the amount of work performed (in ton/kilometers) increased by only $25 \%$, labor productivity $-20 \%$, and the cost has decreased only by $19 \%$. However, as already has been noted, the regularity of flights was not kept significantly, which did not exceed $75 \%$.in the mid-1980s. In fact, the time the passengers had to spend at airports before and after the flight was not decreased. 
That caused the reason why internal republican passenger service by air transport did not actually demonstrate sufficiently significant advantages in terms of speed of movement and comfort compared to rail [Tsdavo, 1976]. As the result, the great share of air transportation in total passenger freight of the republic in 1989 decreased to $8,6 \%$ [Tsdavo, 1976].

\section{Influences}

The negative point in the air passenger transport was unsatisfactory level of passenger service. Thus, in 1965 Kovyuh N. - Head of UUTSA pointed out many shortcomings in service of passengers on local routes, many airports did not organize basic amenities for passengers, and sometimes did not even have adequate facilities for recreation and waiting for departure. For transit passengers they hardly organized direct flights and slowly implemented measures to improve passenger service in resort areas. Serious deficiencies existed in catering of passengers and they did not organize sell of items of first need and press [Goncharov, 1988].

But this was left out of attention of the management leaders of this industry. As the Head of the Service of Passanger Transportation A. Chernyshov reported to the leaders of the management department and the Ministry of civil aviation, in 1976 there were 1464 claims, letters and notifications from passengers. Characteristically, the total number of complaints which criticized the shortcomings due to the fault of the personnel of the enterprises and departments were 363 against 320 that occurred in 1975. Passengers pointed to serious deficiencies in ensuring the regularity of flights, the rudeness and inattention, in violation of the rules of procedure and ticket sales, the poor organization of registration, landing and meeting passengers, bad information and reference work in complaints, letters, statements. Characteristically, many airlines, particular such as: Boryspil, Donetsk, Dnipropetrovsk, Lviv, Simferopol, Kharkiv, Kherson with the planned increase in the number of personnel, including the part, which was directly involved in those gaps connected with passenger service. Thus, the Donetsk, Dnipropetrovsk, Lviv, Simferopol and Kharkiv airlines significantly worsened their operation even in such divisions as information and referral service [Tsdavo, 1983]. It should also be noted that because of numerous cases of basic negligence of employees of airports Ukrainian civil aviation authority always had to indemnify customers for damaged or lost property. The world associate consultant UUTSA G. Banina in the report on legal issues in 1978 stated that the total number of claims and lawsuits, which were in 1978 filed by passengers on the loss, shortage, damage to baggage was 507 cases worth more than 322 thousand . rub. Characteristically however, that claims for losses were satisfied only to 124 claimants for the amount of 80,545 rubles. (growth in comparison with 1977 by the number to 79 and the amount to 3035 rubles.). In general, the various categories of complaints to UUTSA were received: 651 claims and lawsuits in the amount of 640 thousand. rub., for the same period in 1977 432 cases in the amount of 312 thousand. rub., it is more than doubled (the number at 219, the sum of - at 328,517 rubles.) [Tsdavo, 1960].

Not always effectively aircrafts were used during agricultural works too. In particular, the performance of aviachemical works due to organizational and technical reasons always had significant downtime of aircrafts. It should also be noted that there was no proper care to the ground for inter-farm lanes paved. Because of this, in 1976 14 of them were completely inadequate, and a significant number of them were in need of a repair [Tsdavo, 1974]. But funding for the new construction and to maintaining in good condition the existing inter-farm aerodromes was not planned [Tsdavo, 1974].

Often enough the serious difficulties appeared as a result of delays with getting fuel and other air oils. So, in 1983 ukrainian airports were not fully supplied by oil refining plants according to the existing funds of 63500 air fuel, including Lysychansk ORP - 40 thousand tons, Kremenchuk ORP - 23.5 thousand tons [Tsdavo, 1972].

There is a growing trend of increasing downtime of aircrafts for reasons that were dependent on poor organization of most airlines. That is why in 1974, compared with 1971, the downtime due to fault of certain services and the general downtime occurred in UUTSA increased more than twice. Especially great number of the downtime was due to organizational and technical assessment faults of aviators which were in Voroshilovograd united squadron - 53\%, Micholayiv - 47,8\%, Dnipropetrovsk 43,8\%, Zaporizhzhia- 40,3\% [Tsdavo, 1979-1980].

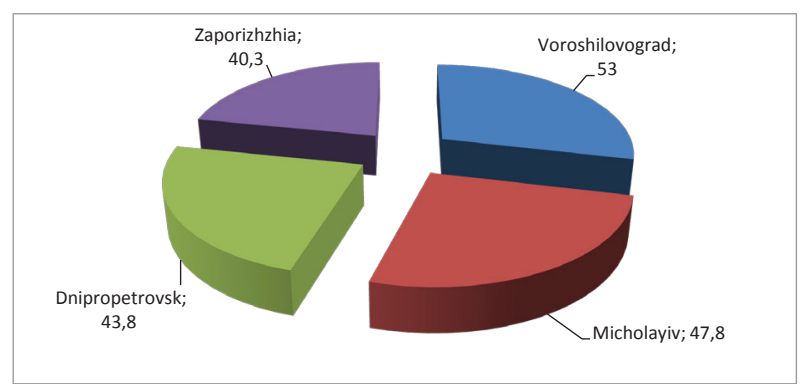

Pic. 2. Volume of systematic downtime in \% (1971)

The use of aircraft in agriculture was accompanied by other negative factors which were mentioned at the third rally of young leaders in agricultural aviation in January, 1976. Many speeches presented evidence of abuse in the operation of airchemical work in agriculture, raised the question of restoring the proper order to the process of flight documentation. It was noted that the governing structure of airlines did not exercise proper control over the airchemical work, which led to numerous false flight time records and size of treated areas records, as well as other disorders - counterfeiting barohram, gross errors in the calculation of treated areas, which reduced the 
effectiveness of the aviation and did not give proper economic effect to the farms. These numerous facts were detected in Kiev, Kharkov, Vinnitsa and on other airlines [Tsdavo, 1979-1980].

Reliability of air transport was not at the proper level. The number of preconditions that could cause aircraft accidents was increasing. Typically, they were the result of poor performance of flight navigator department, technical department and low discipline of the service which supplies with fuel and lubricants [Tsdavo, 1965].

Logically, all these facts led to the growth in the number of avia cases due to the faults of avia specialists, especially among navigators. Thus, in 1974 there were 18 accidents, in 1975 - 12 accidents, in 1976 - 16 accidents 16 [Tsdavo, 1965-1969]. Especially confuses the fact that more than $60 \%$ of catastrophes $50 \%$ of dangerous accidents were the consequences of low professional training of departments of avio navigators and low executive discipline of the land based specialists [Tsdavo, 1965-1969].

One manifestation of this was the improper state of security and fire protection of aircraft parking, which required the creation of access control and secure fencing area of airports, which, however, just was not done in most airports. The Access Control Posts were equipped only in Kyiv, Lviv and Kharkiv. As the transportation safety inspections of air transport show often even standard baggage inspection procedure was not organized properly [Tsdavo, 1990]. As the result there were numerous cases when various hazardous substances were in the luggage [Tsdavo, 1976]. And absolutely unacceptable fact that not all airports had properly equipped fire station [Tsdavo, 1990; Tsdavo, 1976].

\section{Conclusions}

The analysis of fundamental changes in air transport of the Ukrainian SSR in 1960-1980's of XX century shows that this, in general, positive process was also marked with several rather significant and negative moments. Thus, the air transport of Ukraine was characterized by uneven transport work in the regions of the republic, systematic disruption of flights, incomplete aircraft loading and constant underestimation of the planned range. Characteristic features of air transport were: insufficient level of passenger service, improper maintenance of interfarm airfields that adversely affected the use of aircraft in agriculture. The planned volumes of freight traffic were not systematically performed. This chronically reduced economic efficiency of airlines.

\section{References}

Tsdavo (1976). Analys promushlenostey i finansovoy aktivnosti avyapredpryyatyy. F. 184. P. 1, 131-132, 199, 232, 275.

Tsdavo (1976). Analys pisem pasazurov za zetvertui kvartal 1976 UUHA. F. 184. P. 1-2.

Tsdavo (1978). Analys kadrovoy rabotu predpriatey UUHA 1978. F. 184. P. 1-34.

Tsdavo (1976). Zakluchenie proizvodstvenno-hozyaistvennoi deayatelnosty UUHA. F. 184. P. 1-2, 35.

Istoria sotsyalystycheskoy economee SSSR (1980). (T. 6. P. 589). - Moscow: Nauka.

Tsdavo (1976). Spravka, doklad, informaziya po rabote UUHA. F. 184. 1853. P. 1-2, 45-47.

Tsdaho (1987). Lustu ZK KPU, souznuh ministerst pro roboty zaliznuchnogo transporty (18.01.1986-02.03.1987), P. 1, 39.

N.E. Goncharov (1988). Regionalnue problemu razvitiya transportnoy sustemu ukrainskoi SSR: Moscow: Yntytut Kompleksnyh problem tansporta, p. 158-159

Tsdaho (1983). Zapusku, dovidku, informazii viddily transporty ta zvyazky ZK KPY z putan transport ta zvyazky (28.01.1981-22.12.1983).6, p. 25.

Tsdaho (1960). Protocol zakrutogo partyynoho Sobraniya partorhanyzatsyy machine UHUHVF ot 01/10/1961. F. 293. 2 .

Tsdaho (1976). Protocol partsobranyya ekonomicheskih slyzb UUHA. F. 293.1-2, 4-16.

Tsdaho (1974). Protocol otkrutogo sobraniya partorhanyzatsyy partyynoho UUHA 11.26.1974 g (1974) F. 293. 7-8.

Tsdaho (1972). Protocol sobraniya apparata. F. 293. 17, 6, 11-12.

Tsdavo (1979-1980). Analiz sosotoyaniya bezopasnosti poletov. F. 184. 2278. 2-3, 56.

Tsdavo (1965). Reshenie soveta pri yfchalnike UUGA. F. 184. 3-8, 56-74

Tsdavo (1965-1969). Postanovlenie Presidiuma ZK profsousa aviarabotnikov. F. 184, 48.

Tsdavo (1965-1969). Postanovlenie Presidiuma ZK profsousa aviarabotnikov. F. 184, 48.

The economy of the USSR in 1989. (1990). - Kyiv. Technology, 463.

Tsdavo (1976). Doklad nachalnika ypravleniya na tretem slete moloduh peredovikov selhohazyaitvennoi aviazii. F. 184. 32-38. 


\section{Анатолий ГОРБАНЬ ПРОБЛЕМЫ ПОВЫШЕНИЯ ЭФФЕКТИВНОСТИ ПЕРЕВОЗОК ВОЗДУШНЫМ ТРАНСПОРТОМ УССР (1960-1980 гг.)}

Аннотация. Транспорт - один из важнейших отраслей хозяйства. Он обеспечивает производственные связи промышленности и сельского хозяйства, осуществляет перевозки грузов и пассажиров, является основой географического развития труда. Обмен и структура транспортных перевозок, как правило, отражают уровень и структуру экономики, а география транспортной сети и грузопотоков - размещение производительных сил. Основными преимуществами воздушного транспорта являются скорость, качество поставок, географическая мобильность - позволяющая легко расширять и менять трассы. Достаточно важным является историко-экономический анализ воздушного транспорта УССР, а также исследование того, что способствовало развитию перевозок данным видом транспорта, а что сдерживало этот процесс. Цель исследования: выявить, обобщить и проанализировать факторы, которые негативно влияли на организацию работы воздушного транспорта республики и уменьшали эффективность его функционирования. Предмет исследования - воздушный транспорт и его роль в грузовых и пассажирских перевозках. Для проведения анализа перевозок воздушным транспортом, был использован статистический и аналитический методы. В нашей статье исследованы трудности по повышению эффективности перевозок воздушным транспортом УССР; определены факторы, которые негативно влияли на организацию транспортной работы отрасли, найдены характерные для отрасли острые проблемы материально-технической переоснащения. Нами выявлен характер трудностей в повышении эффективности транспортной работы отрасли, а именно, неисполнение основных показателей грузовых перевозок и пассажирооборот, задержка рейсов и неполная загрузка воздушного транспорта. Выводы. Выяснено, что региональные, областные авиапредприятия находились в ненадлежащем материально-техническом состоянии, а за межхозяйственными аэродромами вообще не было установлено должного надзора. Все это порождало условия для систематического нарушения регулярности полетов. Проведенный анализ воздушного транспорту УССР (1960-1980 гг.) дал возможность сделать соответствующие выводы, а именно: для работы воздушного транспорта Украины были характерны неравномерность перевозочной работы по регионам республики, систематические нарушения графика выполнения рейсов, неполная загрузка авиа судов и постоянное занижение плановой дальности полетов. Характерными чертами работы воздушного транспорта были: также недостаточный уровень обслуживания пассажиров, ненадлежащее содержание межхозяйственных аэродромов, что негативно влияло на применение авиации в сельском хозяйстве. Систематически не выполнялись запланированные объемы грузовых перевозок. Все это хронически снижало экономическую эффективность работы авиапредприятий. 